\title{
Scaling up Assisted Natural Regeneration to Intensify Agroecologically Agrosystems Productivity
}

\author{
Issoufou Hassane Bil-Assanou ${ }^{1,}$, Daouda Boukari ${ }^{2}$, Lawali Sitou ${ }^{1}$ \\ ${ }^{1}$ Department of Sciences and Crop Production Techniques, Faculty of Agriculture and Environmental Sciences, \\ Dan Dicko Dankoulodo University, Maradi, Niger \\ ${ }^{2}$ Departmental Directorate of the Environment, Niger
}

Received September 24, 2019; Revised October 28, 2019; Accepted November 10, 2019

Copyright@2020 by authors, all rights reserved. Authors agree that this article remains permanently open access under the terms of the Creative Commons Attribution License 4.0 International License

\begin{abstract}
As an agroecological intensification technique, the scaling up of trees assisted natural regeneration (ANR) could help to protect Sahelian agrosystems and to ensure crop production in the context of high demographic pressure and climatic variability. This study aims to evaluate agronomic and environmental performances of a multi-specific agroforestry parkland arising from a Maradi local community innovations in tree resources management to support their ongoing scaling up. The study site is located in central-south of Maradi region's (Niger) with annual rainfall average amount of $600 \mathrm{~mm}$ and is derived from more than thirty years of trees ANR practice. Pearl millet is the dominant cereal most often in association with cowpea, sorghum or groundnut. Woody trees density was evaluated on radial transects. Water profile and soil bulk density in ANR and non-ANR areas were determined from rainy and dry season soils sampling at depths of $0-50 \mathrm{~cm}, 50-100 \mathrm{~cm}, 100-150 \mathrm{~cm}$ and $150-$ $200 \mathrm{~cm}$. Pearl-millet growth and it yield parameters were monitored in $100 \mathrm{~m}^{2}(10 \times 10 \mathrm{~m})$ plots due to 50 plots in ANR and 50 non- ANR areas. Results showed that the two zones had the same composition for dominant woody trees but the average density was higher in the ANR than non-ANR areas. Tree density was lower in fields in the vicinity of the village than those that are far away in all context. Soil water content was higher in ANR areas under and out of tree canopy than in non-ANR area in surface horizons. However, in deep horizons up to $200 \mathrm{~cm}$, soil water content was higher in H ANR and HC ANR areas than in SC ANR areas, respectively. Apart from seeding density $(F=1.20, P$-value $=0.2756)$, all measured agronomic performance parameters were significantly higher in the ANR than in the non-ANR area. These results show that the ANR practice improve agrosystems productivity in a sustainable manner through increases of crop yield as well as direct incomes to smallholders through wood exploitation from enhanced pruning.
\end{abstract}

Keywords Agroforestry, Demographic Pressure, Land Saturation, Sahel

\section{Introduction}

Expansion of cultivated area to meet an ever-rising food demand due to high demographic growth (3.9\%/year) had led to the degradation of Sahelian agroecosystems for last 30 years (Loireau 1998; Leblanc et al., 2008; Gonzales et al. 2012). Due to excessive timber removal linked to ever-increasing population growth natural forest formations are in an advanced state of degradation (Drame et al., 2008). In rural area in Niger particularly, the cropping systems are mainly rain-fed on sandy soil susceptible to water and wind erosion when wood cover is reduced. At the same time, the observed intensification of the rainfall regimes with extreme events (droughts and floods; Panthou et al. 2014; Taylor et al. 2017) exacerbated soil degradation and decreasing the resilience of crop systems especially for vulnerable smallholders.

Yields were very low and cultivated area per farmer operator are small, despite an increase of cropped area (Guengant \& Banoin 2003; Cappelaere et al. 2009). This fact have resulting in the demise of fallow systems and overexploitation of the limited amount of arable land (Wezel \& Boecker 1998, Valentin et al., 2004). This trend had led to a break in ecological balances and had contributed to the process of desertification (de Miranda 1980; Hiernaux \& Turner 2002; Ali et al. 2007; Leblanc et al. 2008). The infiltrability and fertility of the soil had no longer time to recover and the agrosystems were continued to worsen. The major programs to alleviate land degradation that has been initiated since the 1980s (Vlaar 1992; Yamba 2004) had not been successful.

Several studies showed the "regreening" of the most Sahelian areas through NDVI (Normalized Difference 
Vegetation Index) obtained by satellite remote sensing (Hutchinson and Herrmann 2005, Dardel. et al 2014), instead of desertification (Hein and Ridder, 2006). Although the return to a wetter rainfall regime in the central Sahel through the partial upward trend in annual rainfall since 1990 (Hein and Ridder, 2006; Reinert et al. 2015) is seen as a factor, land management changes have greatly contributed to this trend (Olsson et al. 2004; Yamba 2004). In agricultural areas in south-central Niger like Maradi region, Assisted Natural Regeneration (ANR), as a participatory approach of farm management, has led to increase tree density varied from 10 to 70 per ha (Larwanou et al, 2006). This trend is enlightening results revealing the existence of a strong capacity of local rural populations to innovate and organize themselves in community activities (Yamba, 2004).

Despite the increase of woody cover in managed farms in Maradi region, studies on the evaluation of environmental and agronomic performances of ANR remained scarce (Zarafi et al. 2002; Yamba 2004; Larwanou et al, 2006; Peltier et al. 2008). In this paper, we present some environmental and agronomic performances of the ANR in order to support its scaling up.

\section{Materials and Methods}

\subsection{History and Description of the Study Site}

The Dan Saga site is located in central-south of Niger (1341'43.16' 'N; $\quad$ 0744'7.33'”E; http://satellites.pro/carte_de_Dan_Saga) in Maradi Region ( 100 km East of Maradi) with annual rainfall average amount of $600 \mathrm{~mm}$. It is a multi-specific agroforestry park (Piliostigma reticulatum, Combretum glutinosum, Faidherbia albida mainly) on sandy soil derived from more than thirty years of practice of assisted natural regeneration (ANR). It is an Agro-Ecological Intensification pathways (AEI) aimed to ensure crop yield and incomes of smallholders through wood exploitation from improved pruning. This site is defiantly considered as a symbol of success of the sahelian revegetation (The "Greening" of the Sahel, special issue of the Journal of Arid Environments). It is monitored by the Dan Dicko Dankoulodo University of Maradi research team until 2013 in partnership with the IFAD (International Fund for Agricultural Development) project ProDaf (Family Farming Development Program).

\subsection{Data Collection}

Woody vegetation, pearl-millet yield components and soil characteristics were monitored in ANR and non-ANR areas. Woody vegetation survey has been done in following a systematic sampling on radial transect as recommended by Boudet (1984) according to the open forest formations. Thus, all woody plants were inventoried in $50 \mathrm{~m} * 50 \mathrm{~m}$ delimited plots. On the same transect the plots are separated from each other by $500 \mathrm{~m}$. Pearl-millet yield components were assessed in $100 \mathrm{~m}^{2}(10 \mathrm{~m} * 10 \mathrm{~m})$ plots due to 50 plots in ANR and 50 non- ANR areas. The following variables were carried out:

- $\quad$ Seed hole density (NSP);

- $\quad$ Number of seed hole at the emergence (NSHE);

- $\quad$ Seedling vigor (VAL) ;

- $\quad$ Number of hole at harvest (NPR) ;

- $\quad$ Number of ears at harvest (NER);

- $\quad$ Gross weight (weight of the ear; $\mathrm{PB}$ );

- $\quad$ Net weight (grain weight; PN).

Soil sampling was carried out in rainy and dry seasons in ANR (out-and under cover of trees) and in non-ANR areas at depths of $0-50 \mathrm{~cm}, 50-100 \mathrm{~cm}, 100-150 \mathrm{~cm}$ and $150-200 \mathrm{~cm}$ using a specific auger from SDEC-France (EIJKELKAMP). The specific auger allows to remove an undisturbed soil using calibrated sampling cylinders of 53 $\mathrm{mm}$ diameter incorporated in a cylinder holder. Thus, the moist weight of soil samples was determined directly in fields. In the laboratory, the samples were dried at $70^{\circ} \mathrm{C}$ for at least 3 days. After drying, the dry weight was determined in laboratory on a precision Balance (PGL 12001 Adam Equipment). The soil bulk density, $\boldsymbol{\rho}_{\boldsymbol{d}}$, was determined as follow:

$$
\rho_{d}=\frac{W_{\text {soil }}}{V_{\text {soil }}}
$$

Were $\boldsymbol{W}_{\text {soil }}$ is the soil sample dry weight, $\boldsymbol{V}_{\text {soil }}$ is the volume of the sample dried and weighted.

Then, the volumetric soil moisture, $\boldsymbol{\theta}$, at each depth was calculated using soil and water volume as follow:

$$
\theta=\rho_{d} * W_{w}
$$

Where $W_{w}$ is the weight of water in a soil sample.

\subsection{Data Analysis}

Analysis of variance was performed to test the management (ANR and non-ANR) effects on yield component variables using $\mathrm{R}$ version 3.5.1 software. In addition, a Principal Component Analysis (PCA) was performed to estimate the correlation between yield components and environmental variables (farm management, soil bulk density and soil moisture).

\section{Results}

\subsection{Characterization of the Woody Cover}

Trees average density in the ANR and non-ANR are presented in table 1 . Tree density was higher in ANR area (89.68 tree $\left.\mathrm{ha}^{-1}\right)$ than in non-ANR area $\left(27\right.$ tree $\left.\mathrm{ha}^{-1}\right)$, although the specific composition was the same in the two areas. Whatever the farm management type, tree density was lower in halos near villages than those far away. 
Table 1. Average densities of dominant woody species in agrosystems under ANR and non-ANR at Dan Saga terroir

\begin{tabular}{|c|c|c|c|c|c|}
\hline Context & \multicolumn{2}{|c|}{ tree average density $\left(\mathrm{N} \mathrm{ha}^{-1}\right)$} & $\begin{array}{c}\text { Dominant species in descending order of } \\
\text { density. }\end{array}$ \\
\hline & $\begin{array}{c}\text { Plots near to } \\
\text { the villages }\end{array}$ & $\begin{array}{c}\text { plots at intermediate } \\
\text { distance from the } \\
\text { villages }\end{array}$ & $\begin{array}{c}\text { plots away from the } \\
\text { villages }\end{array}$ & $\begin{array}{c}\text { Average } \\
\text { density }\end{array}$ & \\
\hline $\begin{array}{c}\text { Under } \\
\text { ANR }\end{array}$ & 78 & 88 & 103 & 89.67 & $\begin{array}{c}\text { Combretum glutinosum, Piliostigma } \\
\text { reticulatum, Guiera senegalensis and } \\
\text { Faidherbia albida }\end{array}$ \\
\hline $\begin{array}{c}\text { Without } \\
\text { ANR }\end{array}$ & 23 & 27 & 31 & 27 & $\begin{array}{c}\text { Combretum glutinosum, Piliostigma } \\
\text { reticulatum, Guiera senegalensis, } \\
\text { Faidherbia albida and Acacia nilotica }\end{array}$ \\
\hline
\end{tabular}

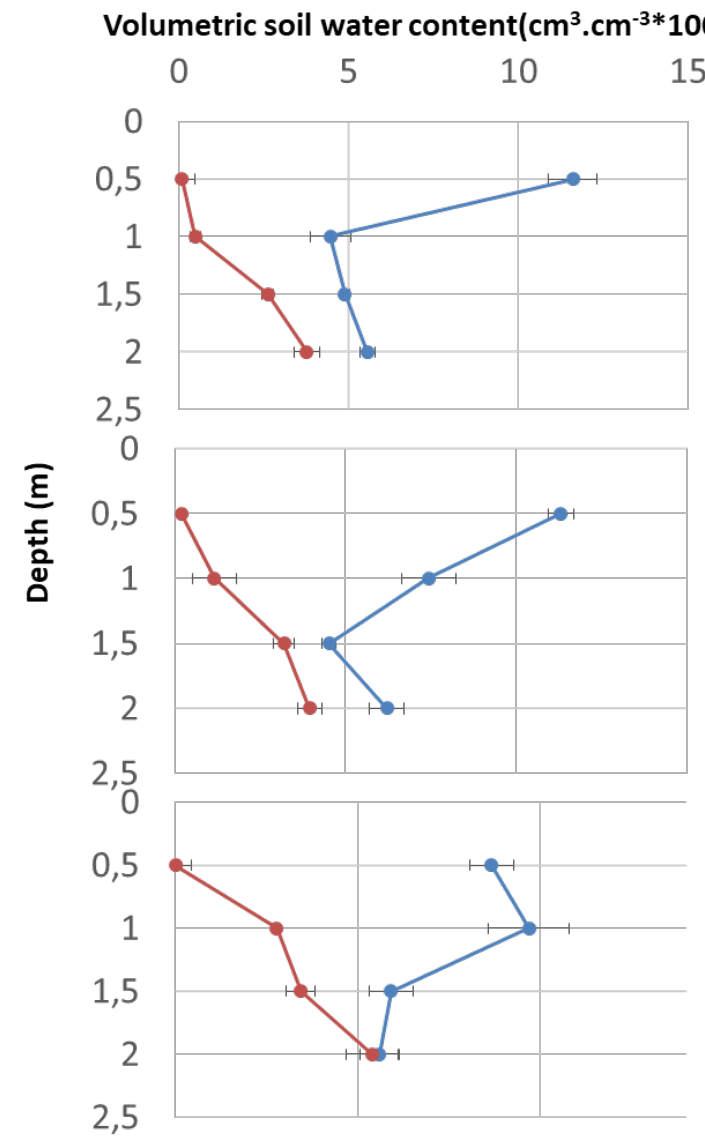

Figure 1. Profiles of soil water content in Dan Saga terroir in ANR (under and out of tree cover) and in non-ANR. In blue measurements made during the rainy season, in red those made during the dry season and bars represent standard errors

\subsection{Soil Water Profile and Soil Bulk Density}

Figure 1 shows seasonal variation of soil volumetric moisture according to the depth in ANR (out-and under tree cover) and in non-ANR. Soil volumetric moisture of the upper soil horizons $(0-50 \mathrm{~cm})$ was higher in ANR area under-and out of tree cover than non-ANR area. However, soil volumetric moisture of the deep soil horizons up to $200 \mathrm{~cm}$ was higher in non-ANR and out of tree cover in ANR areas than under tree cover in ANR area.

Seasonal variation of soil bulk density according to the depth in ANR (out-and under tree cover) and in non-ANR is shown in figure 2. At the depth slices of 0-50 cm and 150-200 cm, soil bulk density was higher in ANR area out of tree cover with high variability than in the two other areas. However, at depth slice of 50-150 cm, soil bulk density was higher in ANR area under tree cover than in the other two areas. 


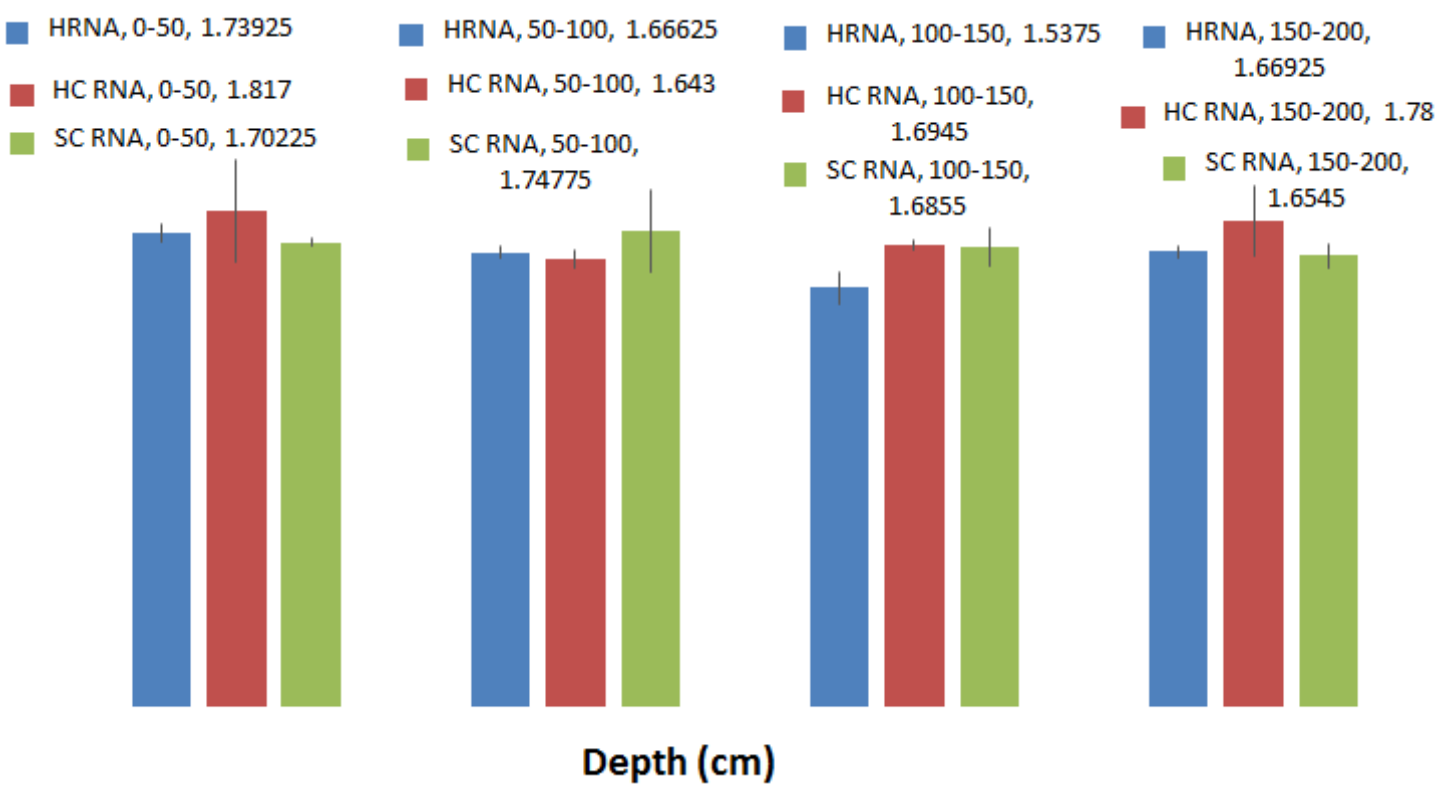

Figure 2. Variation of soil bulk density in ANR (under and out of tree cover) and in non-ANR according to the depth in Dan Saga terroir. In blue measurements made in non-ANR, in red those made in ANR out of tree cover, in green those made in ANR under tree cover and bars represent standard errors

Table 2. Comparison of yield component parameters of millet grown in different contexts under ANR and non-ANR in Dan Saga terroir

\begin{tabular}{|c|c|c|c|c|}
\hline \multirow{2}{*}{ Yield component parameters } & \multicolumn{2}{|c|}{ Contexts } & \\
\cline { 2 - 5 } & Non-ANR & ANR & F & P-value \\
\hline Seed hole density (SHD) & $55.76 \pm 4.5$ & $56.82 \pm 4.98$ & 01.20 & 0.2756 \\
\hline Number of seed hole at the emergence (NSHE) & $36.46 \pm 10.75$ & $47.04 \pm 8.60$ & 30.29 & 0.0000 \\
\hline Seedling vigor (SV) & $20.38 \pm 9.06$ & $27.92 \pm 17.02$ & 07.59 & 0.0070 \\
\hline Number of hole at harvest (NHH) & $33.34 \pm 9.20$ & $49.08 \pm 6.91$ & 95.77 & 0.0000 \\
\hline Number of ears at harvest (NEH) & $134.36 \pm 71.35$ & $217.98 \pm 91.16$ & 26.60 & 0.0000 \\
\hline Gross weight of the ear (GWE) & $70.5 \pm 31.90$ & $114.34 \pm 17.88$ & 74.73 & 0.0000 \\
\hline Net weight of seeds (NWS) & $24.28 \pm 11.50$ & $42.18 \pm 11.64$ & 57.21 & 0.0000 \\
\hline
\end{tabular}

\subsection{Evaluation of the Agronomic Performance of Pearl Millet}

Comparison of pearl-millet yield components cropped under different farm management (ANR and non-ANR areas) is indicated in table 2. Although seed hole density was not varied significantly $(F=1.20 ; P$-value $=0.2756)$, all yield component parameters were significantly lower in non-ANR area than those in ANR one.

\subsection{Relationship between Soil Parameters, Tree Density and Yield Components in Different Farm Management}

Figure 3 shows the relationship between soil volumetric moisture, soil bulk density and pearl-millet yield component. The information contained in the variables is controlled at $67.93 \%$ by axes Dim1 and Dim2. All variables that characterize yield components, tree density, bulk density and moisture of soil at all depth in the superficial part contribute to the formation of the Dim2 axis and are in the same projection as the most plots in ANR. 
Variables factor map

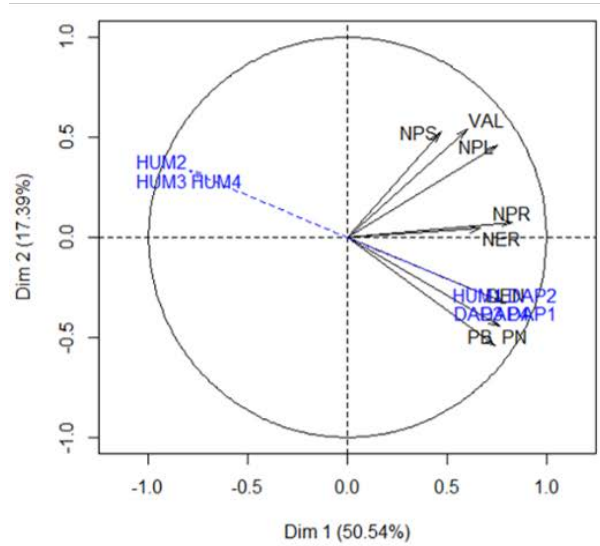

Individuals factor map

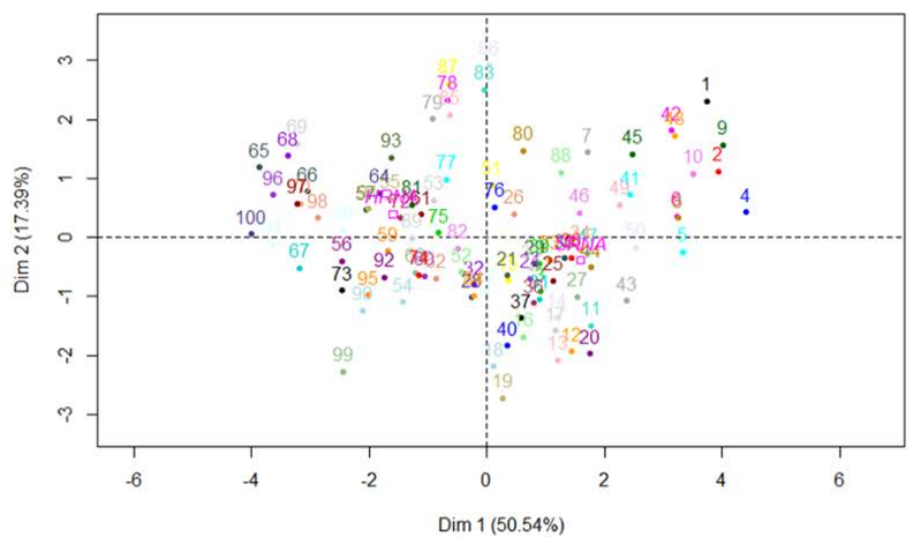

Figure 3. Plan of the Principal Component Analysis (PCA) between yield components and soil parameters in plots in ANR (from 1 to 50) and non-ANR (from 1 to 50). NSP: Seed hole density, NSHE: Number of seed hole at the emergence, VAL: Seedling vigor, NPR: Number of hole at harvest, NER: Number of ears at harvest, PB: Gross weight (weight of the ear) and PN: Net weight (grain weight) for yield components. HUM1 (volumetric soil moisture at $50 \mathrm{~cm}$ ), HUM2 (volumetric soil moisture at $100 \mathrm{~cm}$ ), HUM3 (volumetric soil moisture at $150 \mathrm{~cm}$ ), HUM4 (volumetric soil moisture at 200 $\mathrm{cm}$ ), DAP1 (soil bulk density at $50 \mathrm{~cm}$ ), DAP2 (soil bulk density at $100 \mathrm{~cm}$ ), DAP3 (soil bulk density at $150 \mathrm{~cm}$ ), DAP4 (soil bulk density at $200 \mathrm{~cm}$ ) for soil characteristics. DEN (tree density) for farm management

\section{Discussion}

\subsection{ARN Practice Impact on Biodiversity}

Although the practice of agroforestry is considered as a tool for the conservation and improvement of biodiversity, the willful selection of tree species useful for farmers use is evident in traditional agroforestry systems (Shibu 2011, Shibu 2012). Our results showed the same tree specific composition between the two zones; under ANR and out of ANR. ANR practice in the study area did not result in the improvement of woody plants diversity. However, this practice did simply resulted in an increase in the density of woody species. These results are consistent with those of Morou et al. (2016) who reported low tree specific diversity associate with very high densities of trees with high important value index in Dan Saga.

Indeed, agroforestry is an age-old practice in sub-Saharan Africa involving the association of woody species with crops. But, the woody species are selected according to their utility (fertilizers, no competition, feeding of welding for the humans and the animals ...). ANR remains an agroforestry practice focused on the selection of woody species and the improvement of the conditions of development and growth of these recruits leading to "revegetation" based on an increase in density. in the semi-arid Sahelian zones of Senegal similar to our study area, Grouzis \& Akpo (2006) have shown that tree cover improve floristic composition of the herbaceous layer, enable their phenology, and enhance productivity and quality of the spontaneous herbaceous due to the improvement of edapho-climatic conditions under shading. Furthermore, several studies (Arias et al., 2012, Costa et al., 2012) have shown a strong similarity between the microbial and fungal flora of undisturbed ecosystems and those from agroforestry systems. Our results suggest that the practice of ANR, by increasing the density of woody species, could improve both the floristic composition of herbaceous plants and that of soil microorganisms. Elsewhere, the increase in tree density could improve the quality of habitat leading to the improvement of wildlife and microbial diversity (Ousseini-Niandou et al., 2017; Boureima et al., 2019).

\subsection{Improving Agronomic Performance through the Practice of ANR}

Our results showed very significant increases of agronomic performances of pearl-millet cropped in ANR area compared to crops that are out. In Sahelian regions, Indeed, several studies showed that agro-ecological intensification technologies such as ANR practices, led to double or even triple crop yields in the same conditions for the smallholders (Botoni and Reij 2009). In Niger, pearl-millet yields have increased by 15 to $50 \%$ due to ANR technology adoption compared to the control villages in which it decreased by 25 to $60 \%$. In particular, Toudou et al. (2006) showed that the presence of trees in farms provides yields millet ranging from 100 to $370 \mathrm{~kg} \mathrm{ha}^{-1}$, while in control farms it are in the order of 50 to $270 \mathrm{~kg} \mathrm{ha}^{-1}$. However, our results showed that pearl-millet yield components were not correlated to an increase to the seed hole density. In fact, although the seed hole density did not vary significantly at the time of sowing, our results showed that the numbers of seed hole at emergence and at harvest were higher in ANR area than those in non-ANR one. Indeed, it has been reported that one of the services provided by trees in agroforestry systems is the protection of seedlings against desiccation and silting caused by dusty winds at the beginning of the rainy season. In addition, the 
observed difference in yields will be related to a higher tree density in ANR areas than in non-ANR one. In the ANR areas of the Zinder and Maradi in Niger, Baggnian et al. (2014) reported that millet yield is positively correlated with increasing tree density in the crop fields.

\subsection{Improving Soil Water Fertility through the Practice of ANR}

Our results showed that ANR practice did not improve soil structure because bulk soil density varied from 1.0 to 1.6 g. $\mathrm{cm}^{-3}$ remained the range of values known for sandy soil (Yoro and Godo 1990). In contrast, ANR practice improved soil water availability in the upper horizons favorable to crops. In fact, our results suggest that the increased tree density in crop fields, due to the shading effect and the decreasing in wind speed, would have made it possible to reduce evapotranspiration, which is very important in this region ( $2000 \mathrm{~mm}$ year $^{-1}$; Le Houerou et al. 1988). More generally, it has been reported that, due to the alleviation of ambient air desiccant effect, ANR practice promotes seedling survival (Larwanou et al. 2006).

Our results showed that, beyond $1 \mathrm{~m}$ of depth, the soil moisture was greater in non-ANR area than in ANR one. Indeed, by its deep rooting, the woody stratum contributes to the process the recycling of deeper water and thus contributes to evapotranspiration over a large part of the year (Issoufou et al. 2019).

\section{Conclusions}

The practice of ANR did not allow to improve significant tree diversity because woody species inventoried in ANR and non-ANR areas remained the same in our study zone, but the woody density increased greatly in ANR areas. This Farming Management Natural Regeneration of trees did not, however, improve soil structure, but the presence of woody cover have led to better soil water content in the upper horizons that allowed to increase pearl-millet yields. In a context of high population growth and climate change, the scaling up of ANR could be supported and promoted.

\section{Acknowledgements}

The Authors Are Grateful To Niger Ifad Program (Familly Farming Development Programme; Prodaf) For Funding The Research Team of Dan Dicko Dankoulodo University of Maradi, And To The Nigerien Ministry of The Environment Through Its Departmental Management of Aguié For Technical Support.

\section{REFERENCES}

[1] Ali M, Saadou M, Bakasso Y, Abassa I, Aboubacar I, Karim S (2007) Diachronic analysis of land cover in the Gabi District (Maradi region, Niger) and characteristics of vegetation. Sécheresse 18: 296-304.

[2] Arias RM, Heredia-Abarca G, Sosa VJ, Fuentes-Ramirez LE (2012) Diversity and abundance of arbuscular mycorrhizal fungi spores under different coffee production systems and in a tropical montane cloud forest patch in Veracruz, Mexico. Agroforest Syst 85: 179-193.

[3] Boureima S, Ibrahim M, Ibrahim D, Lawali S (2019) Farming management natural regeneration practices of shrubs promote the development of arbuscular mycorrhizal fungi. Agron. Afr. 31: 1-14.

[4] Cappelaere B, Descroix L, Lebel T, Boulain N, Ramier D, Laurent JP, Favreau G, Boubkraoui S, Boucher M, Bouzou Moussa I, Chaffard V, Hiernaux P, Issoufou HBA, Le Breton E, Mamadou I, Nazoumou Y, Oi M, Ottle' C, Quantin G (2009) The AMMACATCH experiment in the cultivated Sahelian area of southwest Niger-Investigating water cycle response to a fluctuating climate and changing environment. J Hydrol 375: 34-51.

[5] Costa PMO, Souza-Motta MC, Malosso E (2012) Diversity of filamentous fungi in different systems of land use. Agroforest Syst 85: 195-203.

[6] De Miranda E (1980) « Essai sur le déséquilibre écologique et agricole d'une région tropicale semi-aride: Le cas de la région de Maradi au Niger ", Académie de Montpellier, Université des Sciences et Techniques du Languedoc.

[7] Dramé Yayé A, Berti F (2008) Issues around Village Agroforestry in Aguié (Niger). Tropucultura 26: 141-149

[8] Gonzalez P, Tucker CJ, Sy H (2012) Tree density and species decline in the African Sahel attributable to climate. Journal of Arid Environments 78: 55-64.

[9] Grouzis M, Akpo LE (2006) Influence of tree cover on herbaceous above- and below-ground phytomass in the Sahelian zone of Senegal. Journal of Arid Environments 35: 285-296.

[10] Guengant JP, Banoin M (2003) Dynamique des populations, disponibilités en terres et adaptation des régimes fonciers: le Niger. Pub. FAO-CICRED, Rome (ITA), Paris, 142 pp.

[11] Hein L, De Ridder N (2006) Desertification in the Sahel: a reinterpretation. Global Change Biology 12:751-758.

[12] Hiernaux P, Turner MD (2002) The influence of farmer and pastoralist management practices on desertification processes in the Sahel. In: Reynolds, J.F., Satfford Smith, D.M. (Eds.), Global Desertification: Do Humans Cause Deserts? Dahlem University Press, Berlin, pp. 136-147.

[13] Jose S (2011) Managing native and non-native plant species in agroforestry. Agrofor Syst 83: 101-105.

[14] Jose S (2012) Agroforestry for conserving and enhancing biodiversity. Agroforest Syst 85: 1-8.

[15] Larwanou, M., Abdoulaye, M., Reij, C., 2006. Etude de la Régénération Naturelle Assistée dans la région de Zinder (Niger): première exploration d'un phénomène 
spectaculaire. International Resources Group, Washington DC, 67 pp.

[16] Leblanc M, Favreau G, Massuel S, Tweed S, Loireau M, Cappelaere B (2008) Land clearance and hydrological change in the Sahel: SW Niger. Glob Planet Change 61: 135-150.

[17] Loireau M. (1998) - Espaces - Ressources - Usages : Spatialisation des interactions dynamiques entre les systèmes sociaux et les systèmes écologiques au Sahel nigérien. - Ph. D. Thesis, Université de Montpellier III, France.

[18] Morou B, Ounani H, Amadou Oumani A, Diouf A, Guero C, Mahamane A (2016) Characterization of the woody stand demographic structure in the Dan Saga agroforestry parklands (Aguié, Niger). Int. J. Biol. Chem. Sci. 10: $1295-1311$.

[19] Ousseini-Niandou F, Oumani A, Morou B, Lawali S, Issiaka Y, Saidou L, Mahamane A (2017) Inventory of the avifauna in the fields under RNA in the village of Dan Saga in Niger. International Journal of Innovation and Scientific Research 26: 421-428.

[20] Peltier R, Serre Duhem C, Ichaou A (2008) Valoriser les produits du palmier doum pour gérer durablement le système agroforestier d'une vallée sahélienne du Niger et éviter sa désertification. VertigO - la revue électronique en sciences de l'environnement [En ligne], Volume 8 Numéro 1 | avril 2008, mis en ligne le 12 avril 2008, consulté le 21 novembre 2012. URL: http://vertigo.revues.org/1452; DOI: 10.4000/vertigo.1452

[21] Panthou G, Vischel T, Lebel T (2014) Recent trends in the regime of extreme rainfall in the Central Sahel. Int. J. Climatol., 34: 3998-4006.

[22] Reinert M, Janicot S, Aubertin C, Bernoux M, Dounias E, Guégan JF, Lebel T, Mazurek H, Sultan B, Sokona Y, Moatti JP (2015) Changement climatique Quels défis pour le Sud? Marseille: IRD, 2015, 272 p. ISBN 978-2-7099-2172-5.

[23] Toudou A, Reij C, Abdoulaye T, Larwanou M (2006) Impacts des investissements dans la gestion des ressources naturelles au Niger. Rapport d'étude, synthèse première version CRESA, Niamey, 58 pages.

[24] Taylor CM, Belušić D, Guichard F, Parker DJ, Vischel T, Bock O, et al. (2017) Frequency of extreme Sahelian storms tripled since 1982 in satellite observations. Nature 544: 475-478.

[25] Valentin C, Rajot JL, Mitja D (2004) Responses of soil crusting, runoff and erosion to fallowing in the sub-humid and semi-arid regions of West Africa. Agriculture, Ecosystems and Environment 104: 287-302.

[26] Vlaar, J.C.J. (Ed.), 1992. Les techniques de conservation des eaux et des sols dans les pays du Sahel. Rapport d'une étude effectuée dans le cadre de la collaboration entre le Comité Interafricain d'Etudes Hydrauliques (C1EH), Ouagadougou Burkina Faso, et l'Université Agronomique Wageningen (UAW), Wageningen, les Pays-Bas.

[27] Wezel A, Boecker R (1998) Fallow plant communities and site characteristics in semi-arid Niger, West Africa. Journal of Arid Environments 40: 269-280.
[28] Yamba Boubacar. Changes in agrarian systems and types of natural resource use in the central area of Niger. In: Revue de géographie alpine. 2004, Tome $92 \mathrm{~N}^{\circ} 1$. pp. 97-110.

[29] Zarafi AM, Abasse AT, Bokar M, Niang A, Traore CO (2002) Analyse de l'adoption de la régénération naturelle assistée dans la région de Maradi au Niger. 2ème Atelier régional sur les aspects socio-économiques de l'agroforesterie au Sahel. Bamako, 4-6 mars 2002. 